\title{
Cystinotic Fibroblasts Are Depleted of Free- Cystine by Acid pH Medium
}

\author{
DAVID G. RITCHIE, ADAM J. JONAS, ROBERT G. OSHIMA, PATRICIA NEAL, AND \\ JERRY A. SCHNEIDER ${ }^{(18)}$
}

Department of Pediatrics, University of California, San Diego School of Medicine M-009, La Jolla, California, USA

\begin{abstract}
Summary
The free (nonprotein) cystine content of human cystinotic fibroblasts was found to vary with the $\mathrm{pH}$ of their culture medium. Intracellular cystine content was highest at alkaline medium pH's and lowest at acidic medium pH's. When maintained in medium of pH 6.3, cystinotic fibroblasts lost $50 \%$ of their free-cystine content in $6 \mathrm{hr}$ and over $95 \%$ in $30 \mathrm{hr}$. Cystine was the only amino acid to show significant variation with changes in the $\mathrm{pH}$ of the culture medium.
\end{abstract}

Children with nephropathic cystinosis develop several renal tubular malfunction during the first year of life and suffer from end-stage renal failure by 10 years age $(11,12)$. This autosomal recessive disorder of metabolism, which is expressed in fibroblasts, is characterized biochemically by marked elevations of intracellular free (nonprotein) cystine content. While the biologic defect resulting in the accumulation of cystine has not been described, it is known that the increased cystine in these cells is localized in lysosomes and is at least partially derived from protein degradation (14). Chloroquine, which accumulates in lysosomes leading to an increased lysosomal $\mathrm{pH}(3,5,9,15)$ and the inhibition of lysosomal metabolism, also inhibits the accumulation of freecystine by cystinotic fibroblasts (14). Since it is known that changes in extracellular pH may also affect lysosomal function $(4,6)$, we decided to study the effect of extracellular $\mathrm{pH}$ on the cystine content of cultured cystinotic fibroblasts.

\section{MATERIALS AND METHODS}

\section{FIBROBLAST CULTURE}

Human fibroblasts obtained from skin biopsies of two children and a fetus with cystinosis were maintained and assayed for cystine and protein as previously described (8) except that the cells were grown in closed Falcon flasks $\left(75 \mathrm{~cm}^{2}\right)$. Unless otherwise stated, experiments were done using modified F-12 medium (2) supplemented with $10 \%$ fetal bovine serum. Before experiments, the $\mathrm{pH}$ was adjusted by changing the $\mathrm{PCO}_{2}$ or, to obtain higher $\mathrm{pH}$ 's, by adding small amounts of $1 \mathrm{~N} \mathrm{NaOH}$. Experiments were also performed using Eagle's minimal essential medium with 25 $\mathrm{mM}$ Hepes buffer and $10 \%$ fetal bovine serum. The $\mathrm{pH}$ of this medium was adjusted with $1 \mathrm{~N} \mathrm{HCl}$ or $1 \mathrm{~N} \mathrm{NaOH}$ and used with an atmosphere of room air. After incubation, each flask was opened and a sample of the medium was placed into a tube containing mineral oil. The $\mathrm{pH}$ was immediately determined by placing a $\mathrm{pH}$ electrode through the upper layer of oil and into the growth medium (10).

\section{PROTEIN DEGRADATION}

Protein degradation studies were performed according to the method of Bradley et al. (1) The long-lived, stable cellular proteins were labeled by incubating confluent cells in $L-\left[1-{ }^{14} \mathrm{C}\right]$-leucine
$(0.25 \mu \mathrm{Ci} / \mathrm{ml}$, New England Nuclear Co.) for $48 \mathrm{hr}$. The shortlived proteins were labeled with $\mathrm{L}-\left[4,5-{ }^{3} \mathrm{H}(\mathrm{N})\right]$-leucine $(40 \mu \mathrm{Ci} / \mathrm{ml}$, New England Nuclear Co.) which was added to the culture medium and the cells incubated for $30 \mathrm{~min}$. Isotope-containing medium was removed and the cells washed rapidly four times with serum free medium followed by the addition of $3 \mathrm{ml}$ of fresh medium of the appropriate $\mathrm{pH}$, supplemented with $1 \%$ fetal bovine serum. At each time point, the medium was removed and both the $\mathrm{pH}$ and the trichloroacetic acid $(5 \%, \mathrm{w} / \mathrm{v})$-soluble radioactivity were measured. Three milliliters of fresh medium of the appropriate $\mathrm{pH}$ was immediately added for the continuation of the incubation. The total radioactivity of the system was determined for each flask as described (1).

\section{INTRACELLULAR AMINO ACIDS}

Cells were grown in flasks at different pH's as described. After $24 \mathrm{hr}$, cells were harvested by scraping with a rubber policeman and the cellular pellet collected by centrifugation for $4 \mathrm{~min}$ at $1000 \times \mathrm{g}$. The medium was withdrawn and one microcurie of $\left[6,6(\mathrm{n}) \cdot{ }^{3} \mathrm{H}\right]$ sucrose $(3 \mathrm{Ci} / \mathrm{mmole}$, Amersham $\mathrm{Co}$.) was added to 3 $\mathrm{ml}$ of the medium. The cells were resuspended in the labeled medium by gentle mixing and then centrifuged again. The labeled medium was removed and a portion acid precipitated with $12 \%$ sulfosalicylic acid. Forty-five microliters of $5 \mathrm{mM} \mathrm{N}$-ethyl-maleimide were added to the cell pellet which was then broken by sonification (Kontes Cell Disrupter). Cellular protein was precipitated by the addition of $15 \mu \mathrm{l}$ of $12 \%$ sulfosalicylic acid. Aliquots of the cellular and medium supernatants were counted in Aquasol (New England Nuclear Co.). The remaining supernatants were analyzed for amino acid content using a Durram D-500 automated amino acid analyzer. The amount of medium remaining in the cellular supernatant was determined based on the amount of radiolabel in the supernatant. The levels of amino acids determined to be in this amount of medium were subtacted from the cellular supernatant levels, yielding values for intracellular amino acids. The cellular protein was estimated using the procedure of Lowry et al. (7).

\section{R .SULTS}

Cystinotic fibroblasts were depleted of their cystine content by treatment with $1 \mathrm{mM}$ mercaptoethylamine (13) and then incubated for $48 \mathrm{hr}$ in media ranging in $\mathrm{pH}$ from 6.7 to 8.1 . The amount of cystine reaccumulated by the cells varied directly with $\mathrm{pH}$, being lowe' $t$ at acid $\mathrm{pH}$ and highest at basic $\mathrm{pH}$ (Fig. $1 A$ ). Cystine values varie $J$ in a similar manner (Fig. $1 B$ ) when the cells were placed in media of different $\mathrm{pH}$ for $24 \mathrm{hr}$ without prior depletion of their cystine content. Figures. $I A$ and $B$ were obtained with a bicarbonate buffering system. Similar results were obtained using Hepes buffer. When maintained in medium of $\mathrm{pH} \mathrm{6.3,} \mathrm{cystinotic} \mathrm{fibro-}$ blasts lost $50 \%$ of their cystine content in approximately $6 \mathrm{hr}$ and over $95 \%$ in $30 \mathrm{hr}$ (Fig. 2). Cell viability, when studied by either 

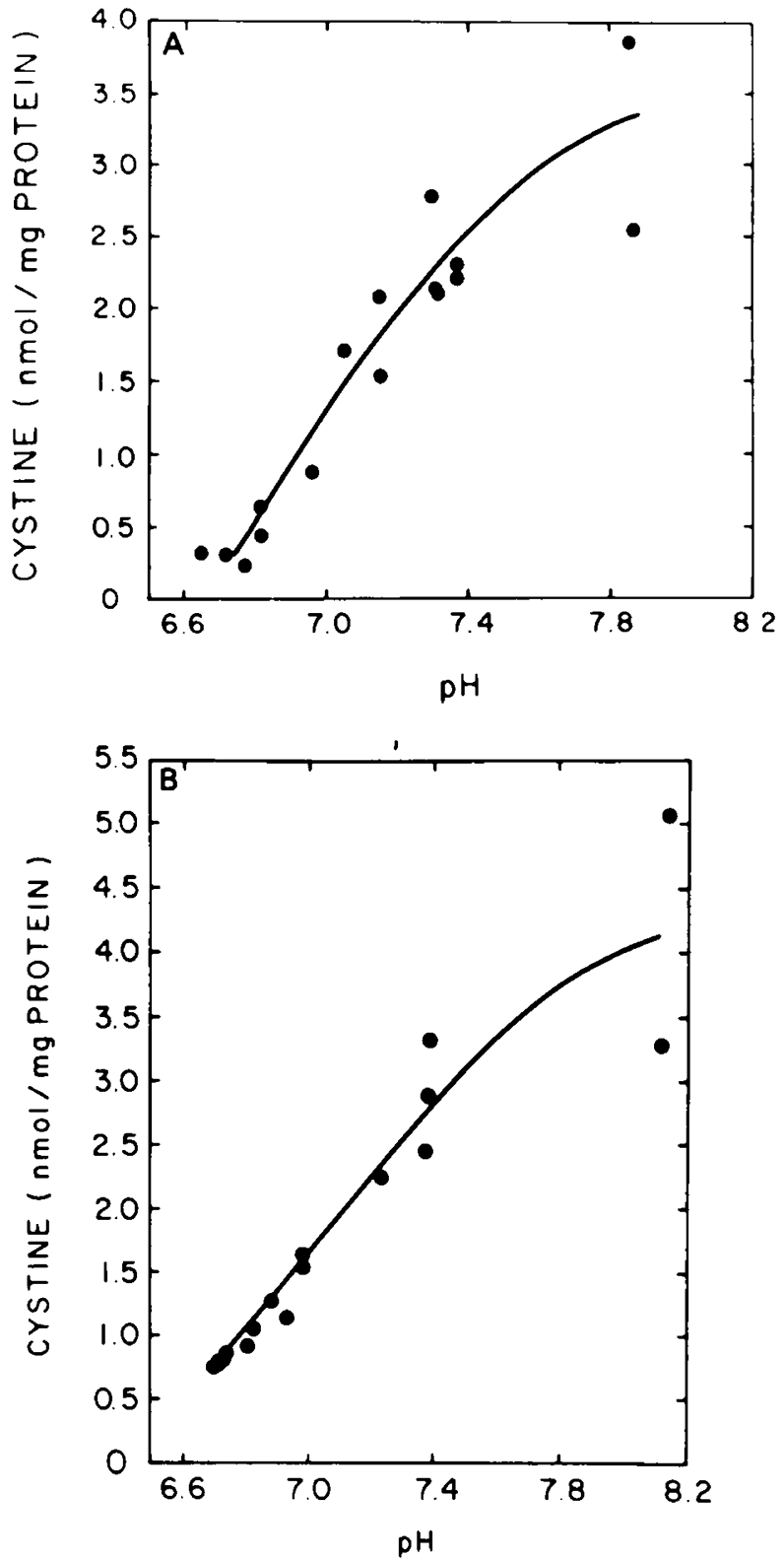

Fig. 1. The effect of media $\mathrm{pH}$ on the free-cystine content of cultured cystinotic fibroblasts at confluency. Cystine values were determined by a binding protein assay ("Materials and Methods"). Cystinotic cells were either treated with cysteamine before incubation at various pH's $(A)$ or were placed directly into media of different $\mathrm{pH}$ 's $(B)$. Each value represents an individual flask of cells.

trypan blue dye exclusion or ${ }^{14} \mathrm{C}$-amino acid incorporation into protein, was not affected by the extremes of $\mathrm{pH}$ used in this investigation. Surprisingly, the appearance of the cells by phase microscopy was also not remarkable at these pH's. The uptake of ${ }^{35} \mathrm{~S}$-cystine by these fibroblasts was not affected by the range of pH's described (data not shown).

Protein degradation studies showed that the degradation of both rapidly $(A)$ and slowly $(B)$ turning over proteins was inhibited when cells were placed in acidic medium (Fig. 3 ). The degradation of rapidly turning over proteins is inhibited by a constant percentage once the cells have been in acidic medium for $6 \mathrm{hr}$. The degradation of slowly turning over proteins is inhibited by an ever increasing percentage during the time that the cells are in acidic medium.

The levels of intracellular amino acids determined in cystinotic fibroblasts grown for $24 \mathrm{hr}$ in minimal essential medium with Hepes buffer at different pH's are shown in Table 1. The data presented are based on three determinations of cellular amino

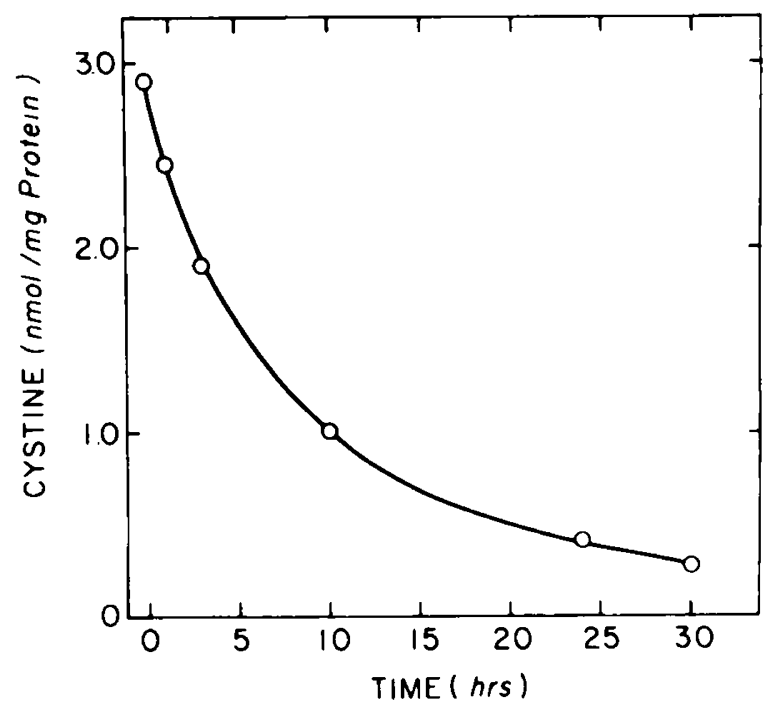

Fig. 2. The effect of acid $\mathrm{pH}$ (6.3) on the free-cystine content of cystinotic cells. Each point is the average of duplicate flasks. The media $\mathrm{pH}$ measurements were all within 0.1 units of the described value $(6.3 \pm$ 0.02 , mean \pm S.E.).

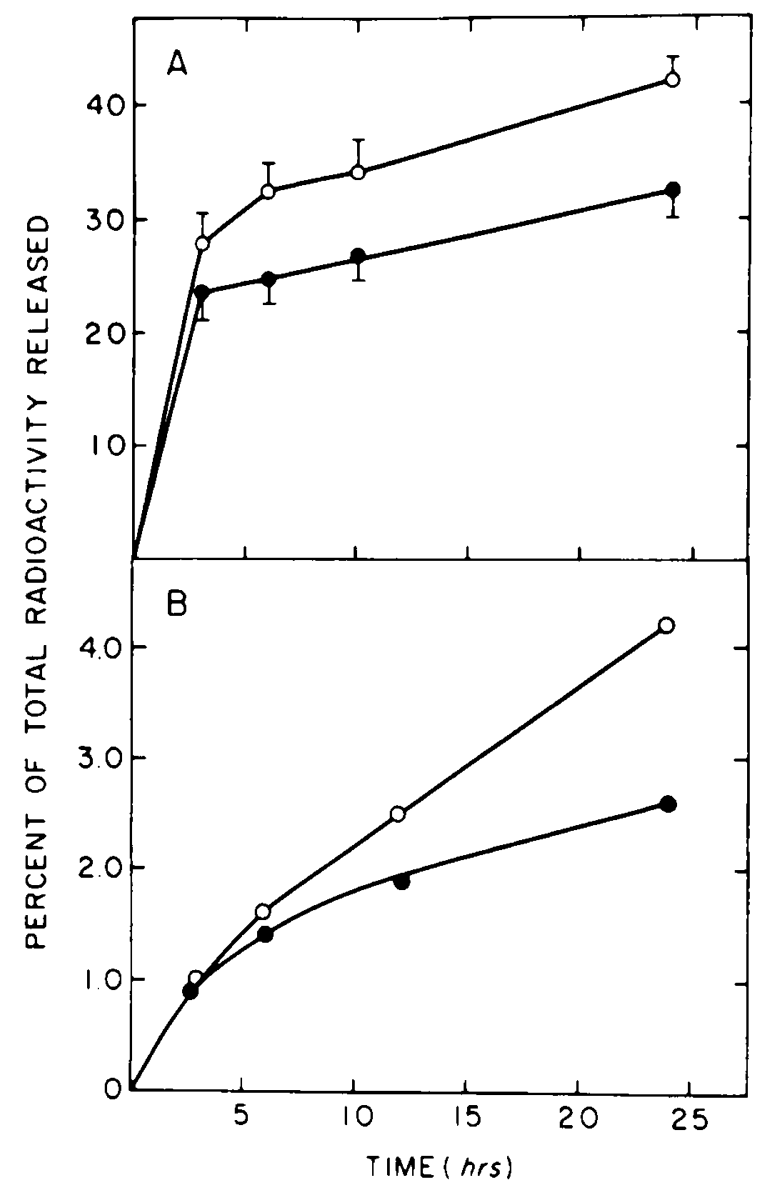

Fig. 3. The effect of media $\mathrm{pH}$ on the degradation of rapidly $(A)$ and slowly $(B)$ turning over intracellular proteins. Confluent monolayers of cystinotic fibroblasts in $25-\mathrm{cm}^{2}$ Falcon flasks were incubated at $37^{\circ}$ with isotope as described in "Materials and Methods". In $A, \mathrm{pH} 7.4$ medium $(O)$ and $\mathrm{pH} 6.8$ medium $(O)$ were added. In $B$, pH 7.1 medium $(O)$ and pH 6.4 medium $(O)$ were added. Each point is the average of triplicate plates $(A)$ or duplicate plates $(B)$.

acids at each medium $\mathrm{pH}$. Cystine is the only amino acid which shows significant variation with the change in medium $\mathrm{pH}$. Aspartic acid could not be measured in this study due to interference by the $\mathrm{N}$-ethylmaleimide adduct of glutathione. 
Table 1. Amino acid concentrations in cystinotic fibroblasts after incubation for $24 \mathrm{hr}$ at different $\mathrm{pH}$ 's

\begin{tabular}{lccc}
\hline & $\begin{array}{c}\text { pH } 6.5 \\
(\mathrm{nmole} /\end{array}$ & $\begin{array}{c}\mathrm{pH} 7.5 \\
\text { Amean } \pm\end{array}$ & $P$ \\
\multicolumn{1}{c}{ Amino acid: } & mg protein) & S.D.) & (Student's $t$ test) \\
\hline Threonine & $5.3 \pm 0.6$ & $8.0 \pm 2.4$ & N.S. \\
Serine & $1.9 \pm 0.7$ & $1.4 \pm 0.3$ & N.S. \\
Glutamic(ine) & $40.2 \pm 11.4$ & $45.6 \pm 5.4$ & N.S. \\
Glycine & $1.8 \pm 0.2$ & $2.5 \pm 0.9$ & N.S. \\
Alanine & $3.4 \pm 0.4$ & $5.5 \pm 1.7$ & N.S. \\
Valine & $5.3 \pm 0.8$ & $5.6 \pm 0.8$ & N.S. \\
Cystine & $4.7 \pm 0.5$ & $7.6 \pm 0.8$ & $<0.01$ \\
Methionine & $1.0 \pm 0.2$ & $1.2 \pm 0.6$ & N.S. \\
Isoleucine & $4.6 \pm 0.9$ & $4.4 \pm 0.3$ & N.S. \\
Leucine & $5.5 \pm 1.6$ & $5.1 \pm 1.0$ & N.S. \\
Tyrosine & $2.6 \pm 0.2$ & $2.8 \pm 0.6$ & N.S. \\
Phenylalamine & $2.0 \pm 0.2$ & $2.3 \pm 1.0$ & N.S. \\
Lysine & $5.8 \pm 1.8$ & $6.4 \pm 3.2$ & N.S. \\
Histidine & $2.7 \pm 2.4$ & $3.4 \pm 1.5$ & N.S. \\
Arginine & $8.1 \pm 1.1$ & $6.6 \pm 2.4$ & N.S. \\
\hline
\end{tabular}

${ }^{1}$ Results for glutamine and glutamic acid are combined.

${ }^{2}$ Nonsignificant $(P>0.1)$.

\section{DISCUSSION}

The lysosomal degradation of protein has been shown to be an important source of the cystine found in cultured cystinotic fibroblasts (14). The decreased turnover of both long- and short-lived intracellular proteins at lowered medium $\mathrm{pH}$ is consistent then with the finding that, under the same conditions, the cystine content of cystinotic fibroblasts is lowered. Not only is a lesser amount of cystine reaccumulated by cells in medium of acid $\mathrm{pH}$, but cells actually lose cystine when the $\mathrm{pH}$ of their medium is lowered. This loss of cystine from cells at low medium $\mathrm{pH}$ is presumably secondary to a $\mathrm{pH}$ dependent equilibrium between the lysosomal efflux and deposition of cystine. The wide range of intracellular cystine content observed at varying $\mathrm{pH}$ levels of extracellular growth media occurred while the cystine content of the medium remained constant at $133 \mu \mathrm{M}$.

Cystine is the only cellular amino acid to vary significantly with medium $\mathrm{pH}$. The isolated effect of $\mathrm{pH}$ on cystine in cystinotic cells may be a reflection of the localization of cystine in lysosomes. Other amino acids that are more widely distributed are apparently not as affected by medium $\mathrm{pH}$. The variation of cystine concentration with $\mathrm{pH}$ does not seem to be related to a generalized loss of amino acids from the cells when they are incubated at lowered $\mathrm{pH}$.

Copyright (C) 1981 International Pediatric Research Foundation, Inc. $0031-3998 / 81 / 1512-1492 \$ 02.00 / 0$

\section{REFERENCES AND NOTES}

I. Bradley, M. O., Hayflick. L., and Schimke, R. T.: Protein degradation in human fibroblasts (WI-38): Effects of aging, viral transformation and amino acid analysis. J. Biol. Chem., 25I: 3521 (1970).

2. Coon. H. G., and Weiss, M. C.: A quantitative comparison of formation of spontaneous and virus produced hybrids. Proc. Natl. Acad. Sci. U.S.A.. 62: 852 (1969).

3. DeDuve, C., DeBarsy, T., Poole, B., Trouet, A., Tulkens, P., and VanHoof, F.: Lysosomatropic agents. Biochem. Pharmacol., 23: 2495 (1974).

4. Lie, S. O., McKusick, V. A., and Neufeld, E. A.: Stimulation of genetic mucopolysaccharidoses in normal human fibroblasts by alteration of $\mathrm{pH}$ of the medium. Proc. Nat. Acad. Sci. U.S.A., 69: 2361 (1972)

5. Lie, S. O., and Schofield, B. H.: Inactivation of lysosomal function in normal cultured human fibroblasts by chloroquine. Biochem. Pharmacol., 22: 3109 (1973).

6. Lie, S. O., Schofield, B. H., Taylor, H. A., and Doty, S. B.: Structure and function of the lysosomes of human fibroblasts in culture: Dependence on medium $\mathrm{pH}$. Pediatr. Res., 7: 13 (1973).

7. Lowry, O. H., Rosebrough. N. J., Farr. A. L., and Randall, R. J.: Protein measurement with the folin phenol reagent. J. Biol. Chem., 193: 265 (195!).

8. Oshima, R. G., Rhead, W. J., Thoene, J. G., and Schneider, J. A.: Cystine metabolism in human fibroblasts: comparison of normal, cystinotic and suspected $\gamma$-glutamyl cysteine synthetase deficient cells. J. Biol. Chem.. 25I: 4287 (1976).

9. Reijngoud. D-J., and Tager, J. M.: Chloroquine accumulation in isolated rat liver lysosomes. FEBS Lett, 64: 231 (1976).

10. Rubin, $\mathrm{H} .: \mathrm{pH}$ and population density in the regulation of animal cell multiplication. J. Cell. Biol., 51: 686 (1971).

11. Schneider, J. A., Schulman, J. D., Seegmiller, J. E.: Cystinosis and the Fanconi Syndrome. In: J. B. Stanbury, J. B. Wyngaarden, D. S. Fredrickson: The Metabolic Basis of Inherited Disease, 4th ed. p. 1660 (McGraw-Hill Book Company, New York, 1978).

12. Schulman, J. D.: Cystinosis. DHEW Publication (NIH) 72-249. (Washington, D.C., Government Printing Office, 1973).

13. Thoene. J. G., Oshima, R. G., Crawhall, J. C., Olsen, D. C., and Schneider, J. A.: Intracellular cystine depletion by aminothiols in vitro and in vivo. J. Clin. Invest., 58: 180 (1976).

14. Thoene, J. G., Oshima, R. G., Ritchie, D. G., and Schneider, J. A. Cystinotic fibroblasts accumulate cystine from intracellular protein catabolism. Proc. Nat. Acad. Sci. U.S.A., 74: 4505 (1977).

15. Wibo, M., and Poole, B.: Protein degradation in cultured cells II. The uptake of chloroquine by rat fibroblasts and the inhibition of cellular protein degradattion and cathepsin B. J. Cell. Biol., 63: 430 (1974).

16. The present address of David G. Ritchie, Ph.D. is: Division of Human Genetics, Department of Human Biological Chemistry and Genetics, University of Texas, Medical Branch, Galveston, TX 77550.

17. The authors thank Vivian Goltsos and Ocean Pellett for their expert technical assistance.

18. Requests for reprints should be addressed to: Jerry A. Schneider, M.D., Department of Pediatrics, M-009, University of California, San Diego, La Jolla, CA 92093.

19. This research was supported by Grants GM-17702 and AM-18434 from the National Institutes of Health and NF 1-373 from the National Foundation. March of Dimes. D.G.R. is an NIH Postdoctoral Fellow supported by Grant a F32 AM05404. A.J.J. is an NIH Postdoctoral Fellow supported by Grant I F32 AM06241.

20. Received for publication February 3, 1981

21. Accepted for publication April 3.1981 